\title{
SOME PECULIARITIES IN THE ILLUSTRATION OF THE FIRST STATEHOOD IN CENTRAL ASIA IN THE 1990s AND EARLY IN THE 21ST CENTURY
}

\author{
Utkir Abdullayev, \\ PhD. Associate Professor of History Department \\ Urgench State University (Uzbekistan)
}

http://dx.doi.org/10.26739/2573-5616-2018-3-1-10

\begin{abstract}
Annotation: The article deals with the illustration of the first state history in Central Asia in Uzbek historiography.

Key words: A.A. Askarov, Sapalitepa, Jarkuton, E.V. Rtveladze, A.S. Sagdullaev, B. Eshov, Q. Sobirov, R.H Sulaymonov, T.Sh. Shirinov, Sh.Sh. Shaydullaev, Kuchuktepa, Afrasiyab, Kuzalikir, Jerkurgan, Kiziltepa, Chust, Eilaton, Bactria, Khorezm, Sogdiana, Fergana.
\end{abstract}

$\mathrm{T}$ he study of the problems of the first state history in Central Asia became an actual task in the 90 s of the $20^{\text {th }}$ century. In the Central Asian nation, there appeared a possibility for research to study the true history of the peoples. However, access to use the results of research was limited due to the fact that there were no constant connections carried out among the Central Asian historian scientists[1].

In the early years of independence, the theory of historical tradition of the Soviet period continued due to the lack of new conceptual approaches to ancient governance and the study of the first statehood. In the context of the characteristics of the first state, it is known that the society was divided into slaveholder and slave class and that slave-based means; Bactria, Sogdiana and Khorezm were described as "large slavery states"[2].

The author's following conclusion in the brochures and articles published at the beginning of the $90 \mathrm{~s}$ of the $20^{\text {th }}$ century is contrary to archeological information: "In the II-I millennium BC, during the time of the Bronze Age, new cities began to appear gradually in Khorezm. In the $8^{\text {th }}$ century BC, the Khorezm state rose to a high level in its political and economic development. Many neighboring tribes, such as the Persians, the Sogdians, the Arses (Herat), began to find refuge under its defense. Larger and smaller tribes and communities became more and more spread in the Khorezm region[3]. 
Some of the reasons for the collapse of the primitive community in Central Asia are mentioned like: "The emergence of surplus property and the creation of inter-group commodity exchanges played a crucial role. There were conflicts, clash and even warfare among the seed groups. The wealth of the family and the seeds that were defeated by these clashes became the property of the winners". According to the ideas of the authors, they turned conquered people into slaves, the private property gradually developed; therefore "elements of society, such as proprietors, slaveholders, obedient and oppressed, slaves and armed forces based on violence, elements of primitive state began to appear[4]. So, according to the authors, the state was based on the struggle of opposing classes, the protection of the interests of oppressive classes and the violence emerged as a political apparatus. However, it is important to remember that the state had positive features in the development of society either.

According to the scientist of ancient period A.A. Askarov, slavery in ancient Central Asia did not develop classically and its meaning was characterized as "patriarchal slavery"[5]. A.A. Askarov and T.Sh. Shirinov pointed out the relationship between the first cities and states and showed the archaeological signs of the first cities[6]. The main features of ancient history and the question of the emergence of statehood were analyzed by A.A. Askarov.

S.S.Kudratov concludes that the Soviet period was regarded as the product of a state-class society in history and it was denied that this process could begin in the primitive period[7]. The classical theory in Soviet times was repeated the same in the researcher's ideas. S.S.Kudratov analyzed the formation of the city-states, the emergence of the kingdoms, the form and structure of the first states. However, it reflected the economic and ethnic factors that led to the formation of statehood.

Sh.Shaydullaev has the following conclusions about the archeological features of the first states, the emergence and development of cities and statehood:

- city - states (states' center of "name" type);

- city - regional state center;

- city - during centralized states, empires[8].

The emergence of the first statehood in Central Asia, including the ancient Bactrian and Khorezm states, was reflected in various historical sources[9]. Their use and critical review can be the basis for new ideas.

A. Anorbaev linked the emergence of statehood in ancient Fergana with the factors such as the development of irrigated agriculture, the increasing of supplementary productions, the capture of prisoners as a result of mutual disagreements and wars, the forced labor, and the rise of class distinctions in the issue of the first statehood in Fergana[10]. These ideas were superior with different forms in Soviet historiography. 
In the literatures, published during the independence years, the ancient history was interpreted with the notion "civilization approach" and the first state and law began to be studied as interconnected processes[11]. E.V. Rtveladze's researches contain information about the emergence and development of ancient statehood in Central Asia, about the types of states, the titles of rulers and military administrative positions[12]. A. Askarov and T. Shirinov say that the formation of the first statehood in the territory of Uzbekistan belongs to the second millennium BC and the appearance of the first states consisted of "city-states" or "oasis-states" in the "name" type (i.e. the city encircled by the wall of defense and its agricultural surroundings).

Researcher A.S. Sagdullaev observed the emergence of new states in the continent due to ethnic migrations and the threat of foreign military aging from ancient times[13]. The author also tried to consider the problems of the forms and chronology of the oldest states in Central Asia[14].

At the same time, the researcher analyzed the essence and significance of economical, social, military-political and territorial functions in the ancient system of governance, the formation of the foundations of governance in the ancient society and the formation of states and came to the following conclusion: "The history of the ancient states of ancient times did not begin with the division of the society into slaveholders and slaves. One of the most important factors of this process is that the division of societies into socially-functional functions without the propagation of property, which is not related to the class antagonism, but depends on socio-economic, military and religious factors"[15].

The researcher stressed that after the formation of political institutions which were considered as the foundations of statehood, they were characterized by the beginning of profound social stratification processes in historical eras.

It serves to abandon the idea that such factors as social inequality, forms of exploitation, division of society into hostile types are the main reason for the formation of the first state. The work of free team members played an important role in organizing the production process of the first state associations.

Historical information in the literature shows that after the formation of state power and political institutions in the ancient East, extra goods and wealth were made according to economical and political reasons, the reputation of some of the richer families was high and this was the cause for the separation of rich people[16]. At the same time, poor social groups appeared in the society and the number of captives and slaves increased at the result of aggressive wars. Due to these processes slavery states developed rapidly. However, it should be considered that the first states of different 
regions had different features and historical norms. The theory that the classes in the old society of Central Asia were the basis of the emergence of states must be clearly proven (i.e. the idea of a class society based on conflict). Historical data suggest that private property, social and property disparities did not develop rapidly during the collapse of the primitive society.

In the history of Central Asia, it is difficult to answer the question of whether the work of free members of the society in the transition period to the state system was a major force in the development of production.

I.V. Pyankov linked the term "vira", "vaysa" and "pariaytar" in "Avesto" with the meaning of "slave", in his opinion "vira"s were slaves of the tribal sects, "vaysa"s were slaves of households. I. Dyankov came to the conclusion that the "slaves of households" - "vaysas" lived under the general roof with free members of the family and became "small" representatives of the society.

According to A. Sagdullaev, the labor of slaves was occupied by farming, domestic cattle breeding and house-keeping. The slaves were fewer than the free members of the society.

In the scientific literature of the $90 \mathrm{~s}$ of the 20th and early $21^{\text {st }}$ centuries, there were mentioned about the following three state associations in Central Asia before the time of Ahamanides: Aryoshayana (Aryanam Vaychakh) "Avesto", political association of provinces ("dakhiyusasti"), Aryanam Vaijo - it's also "dakhiyusasti" or its center "Greater Khorezm" in the southern part of Central Asia or Khorezm State in the lower Amu Darya River and finally ancient Bactrian countries[17].

By analyzing public associations, I.V. Pyankov concluded that Aryoshayana connected the dynasty of "Kavies" (Kayyonies) and established its regional center by Bactria. This conclusion can be taken as hypothesis.

It is possible to agree T. Shirinov's following idea that Bactria and Greater Khorezm states were based on "Asian production" and the Bronze Age's "first class society" was the basis for their the foundations[18].

During the years of independence, many issues related to the first statehood were tied to the problems reflected in Western historiography and Soviet literature. From the late $19^{\text {th }}$ century, researchers had the idea that the origination date of the first states in Central Asia was marked before the time of Ahamanides - the $9^{\text {th }}$ and $7^{\text {th }}$ centuries BC.

But in the years of independence, the origins of the first states and opinions about the states have been developed on a new basis in comparison with the Soviet period researches. The researchers stressed that the emergence of the state should be based on the necessity to fulfill the common interests of the population and that the state's emergence is "not limited with absolute economical factors".

\section{D.A. Alimova and E.V. Rtveladze noted the following main rules of learning the history of the Uzbek statehood:}


1. The appearance of the Uzbek statehood independently of the evolution of ancient civilizations based on ethno-cultural basis.

2. Traditional Uzbek statehood and its gradual development from one stage to another.

3. The diversity of historical forms of Uzbek statehood.

4. Evolutionary improvement of the forms of the statehood in a single process with civilization development[19].

It is important to study the issues of statehood and governance in Central Asia, in close contact with the history of all continents.

The information on the ancient history of Sogdiana has been extensively expanded at the result of the researches carried out during the years of independence by R.H. Sulaymanov, M.X. Isomiddinov, O.N. Lushpenko, A. Raimkulov, M.Kh. Hasanov and French scientists P. Bernar, F. Grene, $\mathrm{K}$. Rapen. The publications of these ancient writers contain some important socio-economic issues[20].

After the independence, a great deal of attention was paid to studying the statehood processes in Khorezm. Yu.A. Rapoport, M.G. Vaynberg[21] who carried out researches in the Soviet period on this issue removed from the idea of S. Tolstov on the issue of "Greater Khorezm", they interpreted his conclusion on the problem of the 6th century on a new basis. Researcher L.T. Yabolonskiy investigated the confederation of nomads and the migration processes associated with saks and examined their impact on the state-owned processes in Khorezm. The researcher V.N. Yagodin also paid a great attention to this issue in his articles and emphasized the fact that the center of the Khorezm state emerged on the shores of Sarikamish Lake and southern Khorezm, and Kuzalikir and Khazarasp were the main centers of it[22]. The results of archeological researches conducted by G.H. Khodjaniyazov are of great importance[23]. In the later periods, the investigations carried out in Khumbuztepa, Teshkirmon oasis and Southern Khorezm by S.B. Bolelov, S. Baratov, Sh. Matrasulov, V.N. Yagodin is related to the history of the Early State, common themes and problems of the history of the peoples of Central Asia. During the years of independence, revision of ethnic and state history in independent countries began independently of each other. In the $90 \mathrm{~s}$ of the $20^{\text {th }}$ century, media, public-political and scientific publications were commented on the critical point of the coverage of the processes in the history of the region.

On this issue, D.A. Alimova, Y.F. Buryakov, M.I. Filanovich, E.V. Rtveladze and A.S. Sagdullayev expressed their opinions through the media. The issues of modern approaches to the history of the peoples of the region were discussed at the international scientific conference held in Tashkent[24]. 
At the international scientific conference on the theme "A New History of Central Asia. Historical Review, Modern Problems and Approaches" M. Abuseitova, D. Alimova, E. Rtveladze, Kh. Pirumshoyev, T. Bakchiev, A. Sagdullaev noted the following problems in addressing the common history and cultural heritage of the peoples of the continent:

- falsification of the past, propaganda of the history of their own state as the oldest in the continent;

- ethnic choice, some people's glory, views on "phenomenon"[25].

The issue of the objective coverage of the history of the peoples of Central Asia on the basis of original sources was put forward in the brochure of E.V. Rtveladze and A.S. Sagdullaev[26]. They noted the need to focus on attempts of researchers to paint the history of the continent's statehood, to use it for political purposes and to raise the artificial level of truth on the basis of misinterpretation of key issues of ancient history[27].

It is not difficult to understand that the history of Central Asian nations is a historical requirement, true lighting is important because the people of the continent have a common history and culture in many respects. According to A.S. Sagdullaev's conclusion, it is primarily important to understand the law of the regional community that promotes the common interests of regional unions. One of the most important conditions for preservation of neighborly relations is the impartial approach to the common history of the peoples of the continent. Non-objective illustration of history is considered as afence on the way of integration and partnership. In today's world, the history of the region is a lack of co-operation in the study of issues such as ethnic history and the scientific finding of statehood.

In the early 1990s, the process of "reobserving" the history of Central Asia by Tajik historians began and it was reflected in the "new" literatures[28].

E.V. Rtveladze and A.S. Sagdullaevs point out that Tajikistan scientists paid attention to the attempts to portray the past, to streamline events and to legitimize the history of some peoples and to try to prove that history can solve problems of the past with legends and legends.

Critically evaluating some "new" concepts, A.A. Askarov made the following conclusions: "Regrettably, in recent years, the idea of panIslamism has been revived in the study of the ethnogenesis and ethnic history of the peoples of Central Asia, and that acts of national disagreements are taking place in the continent"[29].

In the 1990s and early $21^{\text {st }}$ century, the issue of the first statehood in Central Asia became as a daily task. It is clear that no scientifically grounded approaches or theories are unbelievable[30]. Some authors came to the conclusion that the rules of historiography, experiments and scientific data accumulated in the science do not interfere with thought and dissemination of different assumptions. The author's interpretation of the history of the 
first statehood of the region in its own way, the history of the unchallenged sowing community, "new" views and ideas emerging on the basis of modern national turning, subjective approach to historical events lead to the explicit falsification of the history of the peoples of the continent. According to D.A. Alimova, in the '90s, people who realized that their interest in the past could be used through historical sensations and that those who were left out of history had shown their extraordinary abilities[31].

The subject of the new state of Uzbekistan appeared in the subject of historiography. It began in the early 1990s of the past century. The preliminary results of these studies were reflected in articles, monographs, scientific papers, manuals and textbooks.

Based on the above-stated evidence, the following conclusions can be drawn on the ancient system of governance and modern approaches to the history of the first statehood:

- In the 1990s, because of the lack of new conceptual approaches to the study of ancient governance and the subject of statehood, the class theory inherited from the Soviet era retained its supremacy;

- During the years of independence scientists had the opportunity to carry out a new generalized research on the neutral coverage of the ancient statehood of the peoples of Central Asia;

- In the early $21^{\text {st }}$ century, some researchers focused on the diversity of theories on the origin of the state, say that studying and solving the problem was not limited to the theory of class;

- Critically evaluating the essence of statehood theory and the positive aspects of these theories are of great importance;

- The basics, characteristics, and historical development of social justice from the primitive society to political power have not been sufficiently clarified as special subjects;

- New approaches taken in connection with the necessity of realization of the state's emergence, first of all, with the necessity of realization of common interests of the population and society, perception of different aims, tasks and functions of administration took an important place in the history of Uzbekistan;

- At present a class-theoretical approach is also used along with a civilizational approach towards the first statehood history, which requires a critical analysis of the situation;

- The history of statehood and the Soviet era in the countries of Central Asia began to fall away from the study of the original sources. It would be a bad idea to use the subject for political purposes and to raise it to the level of artificiality that can not be denied. 


\section{References}

1. Sagdullaev A. Some problems of the history of Uzbekistan. - T.: Academia, 2001. - P. 130.

2. History and culture of Uzbekistan. - T., 1992. - P. 20-21.

3. Jumaniyozov R. History of ancient Khorezm. - Urgench: 1993. - P. 9, 17.

4. Karimov Sh., Shamsutdinov R. Motherland history (Book 1). - T., 1997. - P. 30-31.

5. Askarov A. History of Uzbekistan. - T., 1994. - P. 197;

6. Askarov A., Shirinov T. Early urban culture in the South of Cetral Asia in the Bronze Age... - P. 98-113.

7. Kudratov S. Appearance of the first states in the territory of Central Asia., 1998. - P. 5.

8. Shaydullaev Sh. Archeological marks of first states. 2002. - № 3. - P. 5.

9. Shirinov T. Ancient kingdom Bactria "Greater Khorezm" $\left(7^{\text {th }}-6^{\text {th }}\right.$ centuries BC. $) / /$ T., 2001. - P. 8-14.

10. Anorboev A. The first statehood in Uzbekistan... - P. 10.

11. Rtveladze E. and others. Civilization of ancient of Uzbekistan - P. 17.

12. Rtveladze E. Titles state rulers and management of Central Asia at the beginning of the $1^{\text {st }}$ millennium B.C.- $3^{\text {rd }}$ and $4^{\text {th }}$ centuries A.D., 2006. - № 5-6. - P. 46-57;

13. Ртвеладзе Э.В., Сагдуллаев А.С. Современные мифы о далеком прошлом народов Центральной Азии (Modern myths about the ancient past people of Central Asia). - Т.: Узбекистан, 2006. - С. 43, 48.

14. Sagdullaev A. Issues of typology and chronology of ancient states in Central Asia., T., - 1992. - P. 132-133.

15. Sagdullaev A., Mavlonov O. History of governing in Uzbekistan. - P. 28-29.

16. Sagdullaev A., Aminov B. History of Uzbekistan. - P. 7.

17. History of Uzbekistan) - T.: Universitet, 1997. - P. 45.

18. Shirinov T. Ancient kingdom Bactria "Greater Khorezm" (7th-6th centuries BC.). T.: Shark, 2001. - P. 12.

19. Alimova D., Rtveladze E. Sketches of the history of statehood in Uzbekistan. - T.: Shark, 2001. - P. 5-6.

20. Bernar P., Grene F., Isamiddinov M. Main results of the discoveries UzbekFrench expedition in Afrasiyab in 1990-1992.- 1994. - № 3-4. - P. 34-42.

21. Rapoport Y. A short narration of the history of Khorezm in the ancient past. -M.: Nauka, 1998. - P.31.

22. Yagodin V. Ancient statehood and problem of "Greater Khorezm" (cycle 1-2). 2007. - № 1. - P. 75-79.

23. Bolelov S. Some results of archeological works in Khumbuztepa. - 1999. - № 9-10 - P. 85-90.

24. History and problems of objectivity and ethics. T., 2003. - P.275.

25. New history of Central Asia. Over evaluation of history, modern problems and approaches.- T., 2004. - P.146.

26. Rtveladze E., Sagdullaev A. Modern myths about the early ancient peole of Central Asia.- T.: Uzbekistan, 2006. - P.50.

27. Rtveladze E. Positive and negative aspects of new researches on the history of Central Asia... - P.127-132.

28. Masov R. History of the basic division. - Dushanbe., 1991. P.355.

29. Askarov A. Ethno genesis and ethnic history of Uzbek nation. - T.: Uzbekistan, 2007. - P. 86.

30. The above source. - P. 6-9.

31. Alimova D. History as a subject during 15 years of independence of Uzbekistan. T., 2006. - № 4. - P.30. 